\title{
EDITORIAL
}

\section{The Week of the 10 May 2021: A Week of State Aid, Transfer Pricing and Tax Rulings}

The week of the 10 May 2021 has proved to be an interesting and significant week for those concerned with EU state aid law, transfer pricing and tax rulings. Monday 10th saw the hearing before the Grand Chamber of Fiat Chrysler's and Ireland's appeals against the September 2019 decision of the General Court ${ }^{1}$ upholding the Commission's finding of state aid granted by Luxembourg to Fiat. ${ }^{2}$ Then on Wednesday 12th the General Court handed down judgments in Amazon ${ }^{3}$ and Engie. ${ }^{4}$ On that, the General Court 'did a Fiat/Starbucks' and found in one case in favour of the Commission and in the other case against it. ${ }^{5}$ The two events indicate that we have not yet reached a final and definitive position on state aid, transfer pricing and tax rulings, but perhaps we are at an interim stage on the journey to a final destination of some clarity and certainty as to the law in this area.

\section{The Fiat hearing}

At the hearing the parties in the Fiat case explained that they had been asked to focus on two issues: (1) the legal basis and scope of the arm's length principle (ALP); and (2) the rules that make it possible to determine whether the setting of a transfer price involves a significant deviation from an arm's length outcome. That these two issues were the focus of the hearing is, of itself, interesting: it suggests first that the Grand Chamber has concerns about the legal basis on which the European Commission has been using the 'ALP' in state aid cases. The second issue might be translated as the Grand Chamber recognizing that (as the General Court has itself recognized) there is a degree of flexibility in determining an outcome based upon the ALP. However, there may be a point where a revenue authority's application of the ALP is so far from 'an arm's length outcome' that this constitutes a misapplication or distortion of transfer pricing rules sufficiently divergent from the arm's length outcome to constitute state aid. Implicit in these topics is a sophisticated understanding of the issues coming up for decision before the Court of Justice, not just in the Fiat case but in other matters that are likely to present themselves to the Court of Justice of the European Union (CJEU) arising out of the Commission's recent investigations of tax rulings.

The Commission's approach to the legal basis for the ALP has not been constant and has undergone a series of changes since the Commission began to open enquiries into tax rulings in 2013. The Fiat case is the first opportunity that the CJEU has to review the Commission's developing approach to the ALP. Hence the comment in opening that we may have reached a mid-point on the journey, but we have not yet reached the final destination as to the role of transfer pricing in state aid investigations.

The current position of the Commission seeks to utilize the ALP as a reference tool which may be employed outside the legal framework and practice of transfer pricing of the Member State concerned. As explained at the Fiat hearing, the Commission currently derives the ALP from the concept of separate entity taxation, and as a logical and inevitable corollary of the separate entity taxation of companies. The elements of selectivity and advantage in state aid analysis lead the Commission to challenge any outcome for members of a multinational group which departs significantly from the tax treatment of a standalone enterprise. Standalone enterprises transact with other companies on the market and so their taxable profits are driven entirely by market-based factors. On that basis, the application of national transfer pricing rules (specifically where there is a ruling such as an advance pricing

\section{Notes}

General Court 24 Sept. 2019, Cases T-755/15, and T-759/15, Fiat, ECLI:EU:T:2019:670.

The two Grand Chamber cases are C-885/19P and C-898/19P.

General Court 12 May 2021, Case T-816/17 and T-318/18, Luxembourg and Amazon EU SARL and Amazon.com Inc v. European Commission, ECLI:EU:T:2021:252.

General Court 12 May 2021, Case T-516/18 and T-525/18, Luxembourg and Engie Global LNG Holding SARL, Engie Invest International SA and Engie v. European Commission, ECLI:EU:T:2021:251.

5 Which is what happened on 24 Sept. 2019, when the General Court decided Starbucks against the Commission, and FIAT in its favour. 
agreement, but also perhaps the rules themselves in the absence of a ruling) should lead to an outcome which is a reasonable approximation of a market-based outcome ('RAMBO').

While this approach of the Commission might seem superficially attractive (one may ask: 'surely a member of a multinational group should be taxed on the same amount of profits as a standalone enterprise carrying out the same business activities?'), there are serious flaws in the Commission's approach which fundamentally undermine it.

First, the starting point for any determination of fiscal state aid must be the national tax system of the Member State concerned. The fiscal aid involves a departure from the 'normal' tax otherwise payable by the enterprise. The lengthy discussions of the reference framework in state aid cases is designed to identify the normal tax which the enterprise would pay under the tax system of the country concerned. It is hard to see in this approach what role there can be for some general concept of an ALP existing outside of the national tax system. If a Member State has transfer pricing legislation which gives priority, for example, to transactional profit split methods of determining transfer pricing, there is really no room for an external ALP to give priority, for example, to a comparable uncontrolled price. Similarly, if a country has chosen not to adopt transfer pricing legislation and hence to have no legal basis for adjusting the profits between associated enterprises, in what way is there a departure from the normal tax system? How could an ALP existing outside the tax system allow the Commission to find state aid based on the failure of the revenue authorities to adjust the taxable profits of a member of a multinational group when there is simply no legal instrument for making that adjustment.

Secondly, it is incorrect to draw a logical conclusion that separate entity taxation necessarily requires transfer pricing based on the ALP. Separate entity taxation in this context is contrasted with the consolidated taxation of members of a corporate group, where the financial results of the members of the group are consolidated, internal transactions are eliminated, and the tax burden on the consolidated group is collected from a representative member of the group. ${ }^{6}$ Under separate entity taxation, each company is separately assessed based on its own profits, and each company is responsible for its own tax liability. In a system of separate entity taxation, it is not necessary, either logically or as a matter of practice, to employ the ALP to determine the profits of each entity.

While preserving separate entity taxation, there are other ways of determining the profit of each entity other than applying the ALP. The most obvious example is formulary apportionment which involves separate entity taxation but without the ALP. The profits of a consolidated group are computed but then those profits are attributed to individual members of the group on a formula basis. Each member of the group then reports its taxable profits, including its apportioned share of the profits of the group, and is responsible for its own tax liability.

Formulary apportionment is not the only alternative to the ALP. Before the more modern development of transfer pricing and its widespread adoption, in many countries the profits of companies would only be adjusted in a scenario where there was evidence of deliberate tax avoidance. ${ }^{7}$ In the absence of evidence of artificial manipulation of profits, no adjustment would take place. If an adjustment was warranted, then typically the legislative provisions gave the revenue authority a wide discretion to adjust the taxable profits. This might or might not be based on an adjustment using assumed market pricing, or any other appropriate approach. One approach would simply be to deny the deductibility in its entirety of an expense that was not wholly incurred for the purposes of the trade but was, instead, shown to have been incurred for tax avoidance purposes.

A third reason why the Commission's approach is unsatisfactory arises from the starting point of comparing members of a multinational group with a standalone enterprise. They are simply not in a comparable position. First, and most obviously, there is no question of adjusting the profits arising to a standalone enterprise in its dealing with 'associated enterprises': by definition it has no associated enterprises. Thus, quite simply, one cannot compare the application of transfer pricing legislation in the context of a multinational group with the taxation of a standalone enterprise which is never subject to such legislation. Secondly, and more fundamentally, there are aspects of the commercial transactions of members of a multinational group that simply do not apply to a standalone enterprise: a member of a group is part of a wider firm and obtains benefits from membership of that wider firm. These may include economies of scale, economies arising from specialization of members of the group in particular functions, shared purchasing power, and other benefits of synergy. Recent transfer pricing developments have sought to consider how the benefits of synergies arising from group membership might be allocated between group members. However, none of those elements could be contemplated within the Commission's simplistic view of an analogy with a standalone entity. As a broad generalization, if the profits of a member of a

\section{Notes}

If understood correctly, this is the German Organschaft system, e.g., It is the basis for consolidated reporting in the US.

This was the case in many British colonies that adopted an income tax following the 1920s, and included in their colonial legislation no provisions for arm's length pricing or transfer pricing, but did contain an anti-avoidance provision allowing the revenue authorities to make an adjustment if the profits of a company had been artificially reduced. The adjustment might or might not involve the substitution of an arm's length price. 
multinational group are exactly the same as those of a standalone entity carrying out the same commercial activities, then that would be quite exceptional, and raises serious questions as to whether the consortium of entities within the multinational group is operating efficiently. If it is operating efficiently, one would reasonably expect higher profits for a member of the multinational group.

Put simply, the position is this. International transfer pricing as represented by Article 9 of the OECD Model seeks to determine an appropriate allocation of profits between different countries based upon an agreed set of transfer pricing guidelines for which the ALP is the underlying principle. The aim is to ensure a fair distribution of profits between two or more states. The ALP as utilized by the Commission to determine whether or not there has been state aid starts from the premise that a member of a multinational group should have the same taxable profits as a standalone enterprise carrying out the same commercial activities. This is a different starting point from Article 9, and follows a different route which is the route of determining whether the state has granted a selective advantage.

If you start from a different point, with a different purpose and direction in mind, then you will end up at a different destination.

Put simply, Commission ALP is not the same as OECD ALP. In a sense the Commission itself accepts that when it says that conformity with the OECD Transfer Pricing Guidelines is likely (but not certain) to ensure an outcome consistent with the Commission's use of the ALP as a tool (i.e., achieving a RAMBO),

It seems from reports of the hearing on Monday 10th that these are some of the issues that the Grand Chamber intends to grapple with in the Fiat case.

\section{Amazon AND Engie}

In many respects the Amazon Judgment (released on Wednesday 12th May) has similarities with the General Court's Judgment in Apple. ${ }^{8}$ The Commission had sought to challenge the transfer pricing analysis presented by Amazon to support a royalty paid between two associated entities in Luxembourg. ${ }^{9}$ As in the Apple case, the General Court carried out a lengthy and highly detailed examination of the grounds on which the Commission challenged the transfer pricing study. The General Court concluded that the Commission, on whom the burden of proof lies, had not satisfied that burden by proving that the transfer pricing study was wrong. The Commission's decision was annulled.

The Commission's challenge to Amazon's transfer pricing reports was based on the Commission's own criticisms of the transfer pricing approach adopted by Amazon's advisers. The primary argument was that, in applying the Transactional Net Margin Method (TNMM), Amazon's advisers had chosen the wrong tested party. There was a secondary argument that Amazon's advisers had been wrong to choose the TNMM; the profit level indicator was wrong; and the cap to the royalty was inappropriate. The criticisms were based on the Commission's own functional analysis and its own understanding of the transfer pricing methodology. On all of these points the Commission failed to satisfy its burden of proof.

One specific point might be highlighted from the judgment. With regard to the determination of the royalty for intellectual property, the Commission sought to rely upon changes made to the OECD Transfer Pricing Guidelines in 2017, after the years under review. The General Court rejected that, and maintained that the Commission could only use the Guidelines as they stood for the years under review. ${ }^{10}$

Perhaps two points arise from the judgment. First, for reasons best known to itself the Commission has not obtained external transfer pricing reports but has made its own internal assessment. The current round of cases may bring to an end the Commission's challenge to transfer pricing rulings: if it does not, then one wonders whether going forward the Commission will obtain external expert reports. If that were to be the case, then the General Court will in the future no doubt find itself in the same position as many tax tribunals around the world: presented with conflicting transfer pricing reports prepared by eminent experts each bringing forth data in support of their different conclusions. One might ask whether that is a task which is appropriate to the General Court - the Amazon case shows that the judges are perfectly capable to rise to the occasion, but is this the best use of their judicial skills? ${ }^{11}$ It also raises the question whether this process should ever be an aspect of state aid regulation.

\section{Notes}

8 General Court 15 July 2020, Case T-778/16, Apple, ECLI:EU:T:2020:338.

9 There are, it should be stressed, notable differences with Apple: for one thing, transfer pricing legislation based upon the ALP was part of Luxembourg law at the time, whereas there were no equivalent rules in Irish law. Apple involved the attribution of profits to a permanent establishment and not a royalty paid between separate enterprises. In Amazon a transfer pricing study had been presented by the taxpayer in support of the royalty between the two enterprises; in Apple the transfer pricing reports presented by Apple and the Irish Government had been prepared in the context of the Commission investigation and on the basis of the counterfactual assumption that the Authorised OECD Approach had been part of Irish law at the time.

10 This, it might be noted, is in contrast to Apple where the General Court did refer to the 2010 OECD Report on the Attribution of Profits to Permanent Establishments (the 'AOA' Report) even though that report was adopted well after the advisory opinions at issue in that case. Apple and Ireland had, however, presented expert reports utilizing the AOA to show that, even if the AOA had been in existence and applicable for the years in question, the outcome agreed in the advisory opinions was consistent within the $\mathrm{AOA}$ and came within the arm's length range of acceptable results.

11 Bearing in mind that tax judges have at times queried whether they are best placed to decide between competing transfer reports prepared and supported by the evidence of different experts. 
On this last point, one perhaps comes full circle to the discussion of the second issue before the Grand Chamber in Fiat. Is a transfer pricing ruling only state aid if it departs so far from a market-based outcome that, given the rules in the national tax system, the conclusion has to be that the ruling offered a selective advantage. That approach is not, logically, the same approach as merely criticizing the transfer pricing of the taxpayer (on grounds that the taxpayer adopted the wrong methodology, or the wrong profit level indicator, or had inappropriate comparables). Such criticisms may disclose a situation where it is likely or possible that the result departs from the marketbased outcome, but it may not of itself prove that. In theory (and this is only in theory) different transfer pricing methodologies when applied to the same facts should lead to the same (or sufficiently similar) taxable profit. Methodological errors need to go further before there is an outcome which is for certain not consistent with a marketbased outcome. It would require evidence that there was a demonstrable market-based outcome, and that the taxable profits determined in accordance with the taxpayer's transfer pricing methodology (as approved in the ruling) departed from that market-base outcome by a margin that could not be explained simply by the highly flexible nature of transfer pricing.

On this point, we are clearly only part of the way along the journey. When the Grand Chamber issues its judgment in Fiat, there may be an indication where the destination might lie.

Engie is a case of a very different nature from Amazon. By a series of rulings, the Luxembourg tax authorities confirmed the tax treatment of a corporate structure that had been employed several times by the Engie group. At the core of this structure was a form of hybrid instrument, a Zero-intérêts Obligation Remboursable en Actions ('ZORA'). This instrument was a loan, convertible on repayment into equity by the issue of shares, with a premium reflecting the profit earned by the borrower over the period of the instrument. The effect of the ZOBA was that the borrower had a deduction such that it paid tax only on a small margin agreed with the Luxembourg authorities, while the lender received ultimately shares in a non-taxable form. It achieved one of the holy grails of tax planners: a deduction against profits for the borrower, with a non-taxable receipt for the lender. The arrangement was internal to Luxembourg, but reduced the taxation base of the operating company to a small margin.

The Commission's Decision finding state aid was challenged on a large number of grounds, but primarily on the basis that the Commission had looked at the transaction as a whole to see its overall effect, and not analysed separately each step of the arrangements, each of which was correctly taxed according to Luxembourg law. The General Court confirmed that the Commission was right to look at the transaction as a whole. Overall, the effect was that substantial profits were taxable only at the low margin agreed with the Luxembourg authorities, and this constituted state aid when compared with the overall purpose of the Luxembourg corporate tax system which was to tax the profits of companies (and not to leave those profits untaxed). ${ }^{12}$

While the primary argument based on a selective advantage would have been sufficient to dispose of the matter, the General Court also examined at substantial length ${ }^{13}$ the application of the Luxembourg abuse of law rule. Luxembourg had not applied that rule in the context of the advance rulings on the ZORA structure: the General Court examined each element of the Luxembourg anti-avoidance rule step by step, concluded that each element was satisfied, and that Luxembourg had also granted state aid by failing to apply the abuse of law rule. Strictly speaking the General Court did not need to consider this issue - its decision on the composite scheme to reduce the tax to a small margin was sufficient. However, the General Court may have had in mind the possibility of an appeal, and that the Court of Justice might wish to consider this alternative ground for sustaining the Commission's decision.

It seems likely that both the Amazon and Engie cases will be appealed. So far as Amazon is concerned, the findings are largely ones of fact which are not open to appeal, but the similarity with other cases which are under appeal means that the Commission may wish to appeal to preserve its position based on the outcome of those other cases. ${ }^{14}$ Engie may wish to appeal, emphasizing perhaps that the ZOBA instrument was available to all companies and was a known element of the Luxembourg tax system. That will raise interesting issues as to whether it is open to a Member State to adopt a measure which is widely available, but results in taxation on only a small, agreed margin of profit; whether granting rulings which confirmed that this was the result under Luxembourg law constituted state aid; and whether a state is obliged to apply anti-avoidance legislation if a structure falls prima facie within its scope. Once again it is clear that we have reached a waypoint on the journey, but not yet reached the final destination of legal certainty and clarity over state aid, transfer pricing, and tax rulings.

Philip Baker

Barrister and QC, Field Court Tax Chambers, Visiting Professor, Oxford University E-mail:pb@fieldtax.com.

\section{Notes}

12 There are interesting similarities here between the approach of looking at the transaction as a whole and the approach to tax avoidance schemes developed in the United Kingdom which also moved from looking individually at each step of an arrangement to looking at the overall effect of the steps combined.

13 Engie (Case T-516/18 and T-525/18), supra n. 5, para. 384-463.

14 Presumably the alternative for the Commission would be to issue a new decision in respect to Amazon, perhaps targeting the structure in other ways, such as the transparent nature of the Luxembourg partnership. 